\title{
TURYSTYKA KONNA JAKO SZANSA ROZWOJU PRZEDSIĘBIORCZOŚCI NA OBSZARACH WIEJSKICH W WOJEWÓDZTWIE KUJAWSKO-POMORSKIM
}

Z a r y s tr e ś c i: Celem opracowania jest zaprezentowanie, że turystyka konna może przyczynić się do rozwoju przedsiębiorczości na obszarach wiejskich województwa kujawsko-pomorskiego. Aby zrealizować cel badawczy zastosowano analizę dostępnych opracowań statystycznych, studia literaturowe oraz badanie ankietowe przeprowadzone wśród ośrodków ogłaszających się na internetowych portalach hippicznych. Przeprowadzone badanie wykazało, że w województwie kujawsko-pomorskim przeważają małe ośrodki jeździeckie i gospodarstwa agroturystyczne.

S ł o w a k 1 u c z o w e: turystyka konna, turystyka jeździecka, przedsiębiorczość, turystyka wiejska, turystyka

K 1 a s y fik a j a J E L: L 21

\section{WSTĘP}

Samorządy lokalne coraz częściej dostrzegają znaczenie turystyki w gospodarce i jej rolę w rozwoju regionów, powiatów, gmin i poszczególnych miejscowości. Rozwój turystyki na danym obszarze może prowadzić również do rozwoju przedsiębiorczości i przyczyniać się do generowania miejsc pracy, zarówno bezpośrednio jak i pośrednio związanych z turystyką. Turysta przebywający w danej miejscowości korzysta bowiem zinfrastruktury, która na co dzień służy mieszkańcom, i która musi być odpowiednio rozwijana by zaspokoić potrzeby turystówi odwiedzających. Dlategorozwój spowodowanywzmożonym ruchem turystycznym zwykle przekłada się na dobrobyt mieszkańców. Tereny wiejskie są zazwyczaj gorzej wyposażone pod względem infrastrukturalnym niż

\footnotetext{
* Adres do korespondencji: Anna Wiśniewska, Uniwersytet Mikołaja Kopernika w Toruniu, Wydział Nauk Ekonomicznych i Zarządzania, Katedra Doskonałości Biznesowej, ul. Gagarina 13a, 87-100 Toruń, e-mail: amw@doktorant.umk.pl;
} 
miasta. Borykają się też z wieloma problemami, np. bezrobociem i wyjazdami młodych ludzi do miast w celu poszukiwania pracy. Rozwój turystyki zachęca do zakładania działalności gospodarczej, co może zaktywizować zawodowo mieszkańców obszarów wiejskich, a przy tym ograniczyć wspomniane negatywne zjawiska.

Atrakcyjna rzeźba terenu, lasy i tereny rolnicze województwa kujawskopomorskiego sprzyjają aktywnemu wypoczynkowi. Dlatego szansą na zwiększenie ruchu turystycznego w regionie może być rozwój turystyki aktywnej i kwalifikowanej. Połączenie sprzyjającego ukształtowania terenu z długimi tradycjami kawaleryjskimi regionu (ośrodek szkolenia kawalerii w Grudziądzu) sprawiają, że specjalizacja w kierunku turystyki hippicznej wydaje się uzasadniona.

Celem tej pracy jest pokazanie, że turystyka konna może przyczynić się do rozwoju przedsiębiorczości na obszarach wiejskich województwa kujawskopomorskiego. Postawiono następujące pytania badawcze:

- Jakie korzyści dla rozwoju obszarów wiejskich niesie rozwój turystyki?

- W jakim stopniu województwo kujawsko-pomorskie jest zagospodarowane pod kątem turystyki konnej?

Aby móc zrealizować cel badawczy przeprowadzone zostało badanie ankietowe wśród ogłaszających się na portalach hippicznych ośrodków jeździeckich. Link do kwestionariusza został wysłany za pomocą poczty elektronicznej trzykrotnie. Wykorzystano również studia literaturowe, a także analizę dostępnych opracowań statystycznych m.in. raportów ze spisów rolnych oraz danych z centralnej bazy danych koniowatych.

\section{PRZEDSIĘBIORCZOŚĆ NA OBSZRACH WIEJSKICH}

$\mathrm{Na}$ przestrzeni wieków powstało wiele definicji przedsiębiorczości. Pod tym pojęciem rozumie się zazwyczaj „cechę działania mającego na celu zapewnienie racjonalnej i efektywnej koordynacji zasobów gospodarczych firmy" [Encyklopedia Zarządzania, bd.]. Niektóre definicje, jak ta przedstawiona przez Sasinowskiego, odnoszą się do sytuacji panującej w otoczeniu. Podkreśla się w niej, że przedsiębiorczość to zbiór „czynników tworzących szanse i sytuacje, w których mogą być zagospodarowane nowe zasoby" [Sasinowski, 2015, s. 88]. Inne definicje przedsiębiorczości odwołują się zaś do osobowych cech przedsiębiorcy, takich jak aktywność, wytrwałość, zapał do pracy, kreatywność, czy zdolność do podejmowania ryzyka [Snarski i Jalinik, 2014, s.7]. Ostatnia $\mathrm{z}$ wymienionych cech jest rdzeniem definicji przedstawionej przez F. Knighta [Marks-Bielska, Babuchowska, Lizińska, 2014, s. 73]. Z kolei 
Schumpeter zaznacza, że przedsiębiorcą można nazwać osobę, która wprowadza innowację. Utożsamiany jest on więc z innowatorem [Glapiński, 2012, s. 8]. Natomiast definicja przedstawiona przez I. Kirzner'a zwraca uwagę na zdolność przedsiębiorcy do dostrzegania, a także wykorzystywania szans rynkowych [Brzozowska, 2016, s. 460]. Przedsiębiorcę można również uznać za lidera, którego „wyróżnia twórczy niepokój” [Glinka i Gudkova, 2011, s. 121].

M. Woźniak wskazuje na czynniki, które mogą wywołać u człowieka postawę przedsiębiorczą. Poza cechami osobowościowymi jednostki wymienia również uwarunkowania lokalne, związane m.in. z krajobrazem i występującym na danym obszarze ruchem turystycznym [Woźniak, 2014, s. 616]. Warta wspomnienia jest również definicja przedsiębiorczości pasjonatów. Jej rezultatem jest działalność gospodarcza, która pozwala przedsiębiorcy na realizację swoich zainteresowań. Jednakże poza pasją do określonego rodzaju działalności, można również wymienić pasję do prowadzenia działalności gospodarczej w ogóle [Glinka i Gudkova, 2011, s. 22].

H. Sasinowski podkreśla rolę samorządu terytorialnego w rozwoju przedsiębiorczości na danym terenie, uznając go obok właścicieli czynników produkcji za inicjatora takiej działalności [Sasinowski, 2015, s. 88]. Biorąc pod uwagę, że w polskim ustawodawstwie sprawy związane z turystyką i jej rozwojem należą do zadań własnych gminy, trudno się z tym stwierdzeniem nie zgodzić. Przedsiębiorczość zarówno jako postawa osób indywidualnych jak i samorządów lokalnych jest uznawana za jeden z czynników rozwoju regionalnego [Kosiedowski, 2001, 32-33].

Według M. Woźniaka [Woźniak, 2014, s. 609] obszary przedsiębiorczości na terenach wiejskich można podzielić na:

- związane z działalnością rolniczą (uprawa roślin, chów i hodowla zwierząt,

- pozarolniczą, ale związaną z rolnictwem bezpośrednio (przetwórstwo, skup płodów rolnych),

- pozarolniczą niezwiązaną z rolnictwem bezpośrednio (turystyka, ochrona krajobrazu),

- handel i usługi.

Turystyka konna pozwala więc łączyć co najmniej dwa z wymienionych obszarów. Wymaga bowiem ona zapewnienia zwierzętom odpowiednich warunków bytowych, a także zadbanie o odpowiednie zagospodarowanie turystyczne. 


\section{TURYSTYKA A ROZWÓJ OBSZARÓW WIEJSKICH}

Opracowana przez Światową Organizację Turystyki (WTO) definicja turystyki brzmi: „Turystyka to czynności osób podróżujących w celach wypoczynkowych, służbowych lub innych i pozostających poza swoim codziennym środowiskiem nie dłużej niż jeden rok." Warto jednak podkreślić, że turysta korzysta z co najmniej jednego noclegu poza swoim codziennym środowiskiem, w przeciwnym wypadku powinien być on raczej określany mianem odwiedzającego [Różycki, 2006, s. 9].

W literaturze zwraca się uwagę na pozytywny wpływ turystyki na rozwój obszarów wiejskich. Co ważne, rozpoczęcie działalności jako gospodarstwo agroturystyczne dla osób posiadających gospodarstwo rolne nie musi wiązać się z dużymi nakładami finansowymi. Oczywiście pod warunkiem, że gospodarstwo znajduje sięw atrakcyjnej lokalizacji, ajego właściciele są wystarczająco kreatywni w wykorzystywaniu własnych, czy też pobliskich zasobów, celem zapewnienia turystom atrakcji. Biorąc pod uwagę fakt, że w Polsce przeważają gospodarstwa małe, które mogą cechować się niewystarczającą efektywnością [Iwicki, 2006, s. 20], rozwój agroturystyki, w tym także turystyki konnej może być dla nich szansą na poprawę swojej sytuacji finansowej. Choćby poprzez zróżnicowanie źródeł dochodów rolników, co pozwala zmniejszyć straty ponoszone w wyniku np. klęsk związanych ze zniszczeniem upraw. Co więcej inwestycja w turystykę wiejską może przyczynić się do zmniejszenia bezrobocia, pomóc promować inicjatywy oddolne, a także zadbać o lokalną kulturę, środowisko i krajobraz [Drzewiecki, 2002, s. 17], stąd też rozwój turystyki na obszarze wiejskim powinien znaleźć się w obszarze zainteresowań samorządu lokalnego. Generowane przez powstające przedsiębiorstwa dodatkowe przychody z podatków mogą pomóc w realizacji niezbędnych inwestycji, koniecznych dla poprawy bytu mieszkańców i przyciągnięcia inwestorów. Turystyka należy do tych branż, których rozwój wspomaga pośrednio rozwój innych gałęzi gospodarki. Konieczne jest bowiem stworzenie pewnego zaplecza, które pozwoli zaspokoić potrzeby turystów związane np. z noclegiem, wyżywieniem, transportem, serwisem sprzętu sportowego, czy szeroko pojętą rozrywką [Jęczmyk i Maćkowiak, 2014, s. 51]. Połączenie tych wszystkich możliwych do osiągnięcia efektów może przyczynić się do ograniczenia wyjazdu młodych ludzi do miast w poszukiwaniu pracy.

Aby rozwój turystyki był korzystny dla obszarów wiejskich musi on spełniać kryteria rozwoju zrównoważonego. Definicja rozwoju zrównoważonego określa go jako rozwój, który „zaspokaja potrzeby współczesnych mieszkańców i gwarantuje zaspokojenie potrzeb przyszłych pokoleń" [Mika, 2008, s. 473]. Jest to ważne, gdyż turystyka pełni również pewne dysfunkcje. Związane są one m.in. z możliwością degradacji środowiska naturalnego, zanikiem bądź zmianą tradycyjnych zachowań i wartości wśród społeczności lokalnej, a także 
utrwalaniem stereotypów. Stąd tak warta podkreślenia jest rola przemyślanego zarządzania turystyką na szczeblu samorządowym.

\section{WARUNKI DLA TURYSTYKI KONNEJ W WOJEWÓDZTWIE KUJAWSKO-POMORSKIM}

W literaturze przedmiotu można zauważyć utożsamianie pojęć turystyka konna i turystyka jeździecka. Jest to jednak niewłaściwa praktyka. Turystyka jeździecka bowiem powinna być kojarzona z uprawianiem sportu jeździeckiego, również na poziomie rekreacyjnym. W takim rozumieniu jest ona formą turystyki kwalifikowanej. Turystyka konna (equestrian tourism), zgodnie z definicją Fédération Internationale de Tourisme Equestre, to „ogół czynności hippicznych podejmowanych przez turystów poza środowiskiem ich codziennego przebywania" [FITE, bd.]. Obejmuje więc ona poza jeździectwem również inne dyscypliny hippiczne, a także m.in. wyjazdy szkoleniowe, przejażdżki bryczką, uczestnictwo w imprezach hippicznych, a także wyjazdy w celu zwiedzenia stadniny, czy kupna konia (również jako inwestycji). Turystyka konna ma więc powiązania nie tylko z turystyką kwalifikowaną, ale również sportową, krajoznawczą, biznesową, wiejską, leczniczą czy edukacyjną.

Organizacja którejkolwiek z form turystyki konnej wymaga odpowiedniej infrastruktury, ale też często również wiedzy i umiejętności instruktorów oraz odpowiedniego wyszkolenia koni. Ważny jest również dobór zwierząt pod względem rodzaju uprawianej turystyki konnej, gdyż inne rasy sprawdzą się lepiej w wyjazdach w teren, inne w pokazach, jeszcze inne w zaprzęgu. Wiele polskich ras koni, cechuje się wszechstronnością, np.: koń wielkopolski, koń małopolski i polski koń szlachetny półkrwi. W użytkowaniu zaprzęgowym sprawdzają się konie śląskie oraz polskie konie zimnokrwiste (sztumskie, sokólskie, łowicko-sochaczewskie i lidzbarskie). Natomiast do długich wypraw w terenie, użytkowania jucznego oraz dla niższych jeźdźców doskonałe będą konie huculskie i koniki polskie [Janiszewska, Cieśla, 2006, s. 30-34]. Z kolei kuce felińskie znajdują zastosowanie jako kuce sportowe dla dzieci i młodzieży [Kuc feliński, bd.].

W tabeli 1 pokazano kształtowanie się pogłowia koniowatych w poszczególnych województwach. Województwo kujawsko-pomorskie w powyższym zestawieniu plasuje się na siódmym miejscu pod względem liczby tych zwierząt na kilometr kwadratowy. Uplasowane wyżej województwa zawdzięczają swoją wysoką pozycję głównie występowaniem na ich terenie dużych ośrodków jeździeckich oraz hodowlanych (państwowych i prywatnych). Zgodnie z danymi ze spisów rolnych w 2010 i 2013 roku zmniejsza się w regionie liczba gospodarstw utrzymujących konie ogółem. 
Tabela 1. Pogłowie koniowatych w poszczególnych województwach w 2016 r.

\begin{tabular}{|c|c|c|c|c|}
\hline Lp. & Nazwa województwa & Liczba koni & \% ogółu & $\begin{array}{l}\text { Liczba koni w przeliczeniu na } \\
\qquad \text { km² }^{2}\end{array}$ \\
\hline 1 & Mazowieckie & 52066 & $17,20 \%$ & 1,46 \\
\hline 2 & Łódzkie & 24383 & $8,10 \%$ & 1,34 \\
\hline 3 & Małopolskie & 20252 & $6,70 \%$ & 1,33 \\
\hline 4 & Śląskie & 15444 & $5,10 \%$ & 1,25 \\
\hline 5 & Lubelskie & 28839 & $9,50 \%$ & 1,15 \\
\hline 6 & Wielkopolskie & 31649 & $10,50 \%$ & 1,06 \\
\hline 7 & Kujawsko-Pomorskie & 17503 & $5,80 \%$ & 0,97 \\
\hline 8 & Podlaskie & 18325 & $6,10 \%$ & 0,91 \\
\hline 9 & Pomorskie & 15660 & $5,20 \%$ & 0,86 \\
\hline 10 & Podkarpackie & 14862 & $4,90 \%$ & 0,83 \\
\hline 11 & Dolnośląskie & 15244 & $5,00 \%$ & 0,76 \\
\hline 12 & Świętokrzyskie & 8609 & $2,90 \%$ & 0,74 \\
\hline 13 & Warmińsko-Mazurskie & 15061 & $5,00 \%$ & 0,62 \\
\hline 14 & Lubuskie & 8442 & $2,80 \%$ & 0,60 \\
\hline 15 & Opolskie & 5315 & $1,80 \%$ & 0,56 \\
\hline 16 & Zachodniopomorskie & 10402 & $3,40 \%$ & 0,45 \\
\hline
\end{tabular}

Źródło: Opracowanie własne na podstawie: Centralna Baza Danych Koniowatych, (2017), http:// cbdk.p1/liczba-koniowatych-2016/\#more-531 [18.03.2017].

Warto zwrócić jednak uwagę, że podczas gdy maleje liczba gospodarstw utrzymujących jednego i dwa konie, wzrasta liczba tych, które utrzymują więcej niż trzy konie. Najwyższy wzrost zanotowano wśród gospodarstw posiadających 3-9 koni [Urząd Statystyczny w Bydgoszczy, 2012, s. 84; Urząd Statystyczny w Bydgoszczy, 2014, s. 54]. Oznacza to, że zainteresowanie chowem większej liczby koni wzrasta, co może być związane ze zwiększonym zainteresowaniem hippiką w regionie.

Ponieważ tereny wiejskie są najlepszym miejscem do uprawiania turystyki konnej należy zwrócić uwagę na rolnictwo występujące w województwie kujawsko-pomorskim w zakresie dotyczącym przede wszystkim chowu i hodowli koni. W województwie kujawsko-pomorskim gospodarstwa do 10 ha stanowiły w 2013 r. ponad połowę ogólnej liczby gospodarstw [Urząd Statystyczny w Bydgoszczy, 2014, s. 29]. Takie gospodarstwa, jak wspomniano wcześniej, mogą się borykać z problemem opłacalności prowadzonej produkcji roślinnej i zwierzęcej, stąd zdywersyfikowanie ich działalności, np. poprzez prowadzenie agroturystyki jest pożądane. W 2013 r. gospodarstwa agroturystyczne stanowiły $17,5 \%$ gospodarstw o powierzchni od 5 do 10 ha [Urząd Statystyczny w Bydgoszczy, 2014, s. 30], można więc uznać, że mieszkańcy terenów wiejskich w regionie wykazują zainteresowanie rozwojem turystyki właśnie na tych obszarach. 


\section{WYNIKI BADAŃ}

W terminie 08.12.2015 r.-29.02.2016 r. przeprowadzono badanie kwestionariuszowe $\mathrm{w}$ formie ankiety internetowej, wysłanej za pomocą poczty elektronicznej do 75 ośrodków z województwa kujawsko-pomorskiego ogłaszających się na portalach hippicznych, które w swoich ofertach podawały informację o możliwości jazdy konnej bądź kupna koni. Wykazało ono, że te przedsiębiorstwa niewystarczająco wykorzystują Internet i media społecznościowe do promowania swojej działalności. Aż 11 wybranych do badania obiektów nie podało aktualnego adresu e-mail. Mimo, że $64 \%$ ośrodków ma stronę www, a $69 \%$ profil na facebook'u, zaledwie $65 \%$ ośrodków regularnie aktualizuje ich zawartość. Zwrot $\mathrm{z}$ ankiety wyniósł 20\%. 33\% respondentów określiło profil swojej działalności jako ośrodek jeździecki, 27\% stanowiły gospodarstwa agroturystyczne, po $13 \%$ - ośrodki hipoterapii i inne, po $7 \%$ stadniny i kluby jeździeckie. Warto podkreślić, że określenie profilu działalności jako ,inne" może być związane z tym, że ośrodki mogą prowadzić działalność w kilku wymienionych w ankiecie obszarach, np. nauczać jeździectwa i hodować konie.

Wśród respondentów znajdowały się przede wszystkim przedsiębiorstwa małe, trzynastu respondentów (87\%) zatrudniało poniżej 5 pracowników. Tylko jeden respondent zatrudniał 12 pracowników, lecz było to związane $\mathrm{z}$ posiadaniem dużego zaplecza noclegowego. Zdecydowana większość respondentów zatrudniała 0-2 pracowników i korzystała z pracy takiej samej liczby wolontariuszy. Dwa ośrodki korzystały z pracy 3-5 wolontariuszy, a cztery - od 6 do 8. Jedyny respondent zatrudniający powyżej 9 pracowników nie korzystał w ogóle z pracy wolontariuszy.

Do niezbędnych elementów infrastruktury poza wyposażeniem ośrodków jeździeckich (gospodarstw agroturystycznych) należą również odpowiednio przygotowane i prawidłowo wytyczone szlaki konne i zaprzęgowe. Zgodnie z polskim prawem, niedozwolona jest jazda konna po lasach państwowych poza wyznaczonymi szlakami. Jazda konna jest dopuszczalna jedynie drogami leśnymi wyznaczonymi przez nadleśniczego (art. 29 ust. 1a ustawy z dn. 28 września 1991 r. o lasach). Niepokojący jest więc fakt, że zaledwie 33,3\% respondentów wskazała obecność szlaków konnych, a 26,7\% szlaków zaprzęgowych w swojej okolicy. $80 \%$ respondentów potwierdza, że w ich pobliżu znajdują się szlaki rowerowe, a $60 \%$ wskazuje na obecność szlaków pieszych. $6,7 \%$ respondentów twierdzi, że w ich okolicy nie ma żadnych szlaków turystycznych.

W kwestionariuszu ankiety dokonano rozróżnienia pomiędzy liczbą koni $\mathrm{w}$ danym ośrodku, a liczbą koni udostępnianych klientom. Ma to związek z obecnością źrebiąt i koni starszych oraz prywatnych, z którymi turyści nie mają kontaktu, bądź jest on z różnych powodów ograniczony. $60 \%$ respondentów 
udostępnia klientom 1-10 koni, co pozwala stwierdzić, że ośrodki posiadające małą liczbę tych zwierząt najczęściej występowały wśród respondentów. Między 11 a 20 koni udostępniało klientom 33,3\% respondentów, można je więc określić jako średnie. Co ciekawe jeden z respondentów nie udostępniał turystom żadnego z posiadanych zwierząt, jednakże była to stadnina, a więc ośrodek hodowlany. Żaden $\mathrm{z}$ respondentów nie udostępniał klientom więcej niż 20 koni.

W zakresie zagospodarowania turystycznego regionu pod kątem zakwaterowania, aż 33\% respondentów nie oferuje swoim klientom miejsc noclegowych. Podobny jest odsetek ośrodków, na terenie których turysta nie może skorzystać z wyżywienia.

\section{PODSUMOWANIE}

Biorąc pod uwagę powyższe rozważania można stwierdzić, że rozwój turystyki konnej w województwie kujawsko-pomorskim może być szansą na rozwój przedsiębiorczości na obszarach wiejskich. Przeprowadzone badanie wykazało, że wśród istniejących ośrodków jeździeckich i gospodarstw agroturystycznych przeważają małe przedsiębiorstwa, zatrudniające do pięciu pracowników i udostępniające swoim klientom do 10 koni. Niepokojący jest jednak stan zagospodarowania turystycznego pod kątem turystyki konnej. Znaczny odsetek badanych ośrodków nie oferuje noclegów ani wyżywienia. Nieliczne szlaki konne i zaprzęgowe również nie sprzyjają rozwojowi turystyki konnej. Można uznać, że potencjał województwa kujawsko-pomorskiego w tym zakresie jest niewystarczająco wykorzystywany. Brakuje rozwiązań systemowych i dobrej woli samorządów lokalnych, a także współpracy między nimi, właścicielami ośrodków jeździeckich i organizacjami jeździeckimi działającymi w regionie. To właśnie samorządy lokalne wg. Sasinowskiego są inicjatorami przedsiębiorczości na danym terenie.

Biorąc pod uwagę dane statystyczne z powszechnych spisów rolnych można zauważyć, że wzrasta zainteresowanie utrzymywaniem większej ilości koni $\mathrm{w}$ celu udostępniania ich turystom. Zasadne jest więc stwierdzenie, że mieszkańcy obszarów wiejskich dostrzegli szansę pojawiającą się w otoczeniu, a więc wykazali się przedsiębiorczością. Być może warto by było zintegrować ich działania w celu stworzenia produktu turystycznego dla województwa opartego o turystykę konną.

\section{LITERATURA}

Brzozowska A., (2016), Teorie przedsiębiorczości [w:] Klincewicz, K. (red), Zarządzanie, organizacje i organizowanie - przegląd perspektyw teoretycznych, Wydawnictwo Naukowe Wydziału Zarządzania Uniwersytetu Warszawskiego, Warszawa. 
Centralna Baza Danych Koniowatych, (2017), http://cbdk.pl/liczba-koniowatych-2016/\#more-531 [18.03.2017].

Drzewiecki M., (2002), Podstawy agroturystyki, Oficyna Wydawnicza OPO, Bydgoszcz.

Encyklopedia Zarządzania, (bd.), https://mfiles.pl/pl/index.php/Przedsi\%C4\%99biorczo\%C5\% 9B\%C4\%87 [18.03.2017].

FITE, (bd.), https://en.fite-net.org/content/view/full/12260 [18.03.2017].

Glapiński A., (2012), Schumpeterowska teoria przedsiębiorcy, czyli skąd się bierze pies, „Konsumpcja i Rozwój”, nr 1/2012 (2).

Glinka B., Gudkova S., (2011), Przedsiębiorczość, Wolters Kluwer, Warszawa.

Iwicki S., (2006), Zagospodarowanie turystyczne obszarów wiejskich, WSG, Bydgoszcz.

Janiszewska J., Cieśla A.,(2006), Hodowla i użytkowanie koni z elementami hipoterapii, Akademia Rolnicza w Szczecinie, Szczecin.

Jęczmyk A., Maćkowiak M.,(2014), Przedsiębiorczość w agroturystyce [w:] Snarski S. J., Jalinik M. (red.), Przedsiębiorczość w turystyce, Agencja Wydawnicza EkoPress, Białystok.

Kosiedowski W., Teoretyczne problemy rozwoju regionalnego [w:] Kosiedowski W. (red.), Zarządzanie rozwojem regionalnym i lokalnym. Problemy teorii i praktyki, TNOiK, Toruń.

Kuc feliński, (bd.), https://pl.wikipedia.org/wiki/Kuc_feli\%C5\%84ski [17.02.2016].

Marks-Bielska R., Babuchowska K., Lizińska W., (2014), Agritourism as a form of business activity in rural areas, „Acta Scientiarum Polonorum. Oeconomia”, nr 13 (3).

Mika M., (2008), Przemiany pod wptywem turystyki na obszarach recepcji turystycznej [w:] Kurek W. (red.), Turystyka, PWN, Warszawa.

Różycki P., (2006), Zarys wiedzy o turystyce, Proksenia, Kraków.

Sasinowski H., (2015), Zarządzanie publiczne jako element innowacyjności i przedsiębiorczości w gospodarce turystycznej, „Ekonomia i Środowisko”, nr 4 (55).

Snarski S. J., Jalinik M. (red.), (2014), Przedsiębiorczość w turystyce, Agencja Wydawnicza EkoPress, Białystok.

Urząd Statystyczny w Bydgoszczy (2012), Charakterystyka gospodarstw rolnych w 2010r. w województwie kujawsko-pomorskim, Bydgoszcz.

Urząd Statystyczny w Bydgoszczy (2014), Charakterystyka gospodarstw rolnych w 2013 r. w województwie kujawsko-pomorskim, Bydgoszcz.

Woźniak M., (2014), Przedsiębiorczość turystyczna kierunkiem rozwoju atrakcyjnych krajobrazowo gmin wiejskich, „Prace Naukowe Uniwersytetu Ekonomicznego we Wrocławiu”, nr 366.

\title{
EQUESTRIAN TOURISM AS A CHANCE TO INDUCE ENTREPRENEURSHIP DEVELOPMENT IN THE RURAL AREAS OF THE KUYAVIAN-POMERANIAN VOIVODESHIP
}

\begin{abstract}
The aim of the paper is to show that equestrian tourism may induce entrepreneurship development in the rural areas of the Kuyavian-Pomeranian voivodeship. In order to achieve the purpose of the research there was carried out a survey among equestrian centers that are advertised on equestrian portals as well as the study of available literature and statistical reports. Conducted research showed that small agritouristic farms and equestrian centres are most common.
\end{abstract}

Keywords: equestrian tourism, riding tourism, entrepreneurship, rural tourism, tourism 
